\title{
Sustainable Administrative Reform Movements Policy in Joko Widodo's Administration
}

\author{
Yogi Suprayogi Sugandi
}

\begin{abstract}
Joko Widodo (Jokowi) is a leader that is widely expected to transform Indonesia into a better country. Hopes and wishes were rising when he was elected as the president of Indonesia. This paper will describe various innovations undertaken before and after his presidential inauguration as well as the assorted innovations made in reforming the administration of his cabinet. As the president of Indonesia, Joko Widodo is required to realize the aspirations of the people in freeing the government from corruption, collusion and nepotism. The management of ministerial and non-ministerial institutions becomes the very first crucial issue undertaken by Joko Widodo. This led to a polemic in regards to reducing or increasing the number of institutions, as the Jokowi administration actually increased the amount. In Susilo Bambang Yudhoyono's administration, several policies were made systematically and based on legislations that had been approved by the legislature. Joko Widodo's administration is more partial in nature. The administrative reform program that is highly anticipated is the continuation of the Public Service Act. This law is a step forward from the administrative reform program that aims at the creation of good governance. Changes in career path, salary system, pension and benefits for civil servants, performance-based staffing are various efforts of sustainability carried out by Joko Widodo's administration.
\end{abstract}

\section{Keywords:}

sustainable; administrative reform; movements and policy.

\begin{abstract}
Abstrak
Joko Widodo (Jokowi) sebuah fenomena pemimpin yang diharapkan dapat mengubah Indonesia lebih baik, harapan dan keinginan menjadi terbuka lebar saat beliau terpilih. Tulisan ini akan mendeskripsikan berbagai inovasi Joko Widodo sebelum dan sesudah terpilih menjadi presiden dan berbagai inovasi yang dilakukan dalam mereformasi administrasi kabinetnya. Joko Widodo sebagai presiden Indonesia diharuskan melanjutkan cita-cita rakyat untuk mengeluarkan pemerintahannya dari jerat korupsi, kolusi dan nepotisme. Pengelolaan lembaga-lembaga kementerian dan non kementerian (menambah dan mengurangi lembaga) menjadi isu krusial yang dilakukan oleh Joko Widodo. Menimbulkan polemik karena dari segi jumlah justru semakin bertambah. Pada Pemerintahan Susilo Bambang Yudhoyono, berbagai kebijakan bersifat sistematis dan berdasarkan perundangan yang sudah disepakati oleh legislatif, berbeda dengan pemerintahan Joko Widodo yang bersifat parsial. Keberlanjutan berbagai program reformasi administrasi yang sangat dinantikan adalah keberlanjutan undang-undang tentang Aparatur Sipil Negara. Undang-undang ini sebagai sebuah langkah maju dari program reformasi administrasi yang memiliki target terciptanya good governance government. Perubahan pola karir, sistem pengupahan dan tunjangan untuk Pegawai Negeri Sipil, serta pola kepegawaian yang berkinerja adalah berbagai keberlanjutan Pemerintahan Joko Widodo.
\end{abstract}

\section{Kata kunci:}

keberlanjutan; reformasi ddministrasi; gerakan dan kebijakan.

\footnotetext{
- Senior Lecturer of Department of Public Administration, Universitas Padjadjaran, Bandung.

Email: yogi.suprayogi@unpad.ac.id
} 


\section{Introduction}

Joko Widodo's administration is the currently reigning government in Indonesia. He started his political career as a mayor of a small town in Central Java. Joko Widodo's career ascended by becoming governor of the Jakarta Special Capital Region. His achievement began gaining acknowledgement when he was able to innovate development in the region by building a strong bureaucracy and was able to support regional development. One of his innovations, as an example, is designing information-and-technology-based services for consumer queues at the district office. Joko Widodo's then became the governor of the Special Capital Region of Jakarta, wherein he made a number of development innovations by his highly-frequent unannounced inspections to several public service offices in Jakarta. Such unannounced inspections were sufficient in improving the performance of bureaucracy in Jakarta at that time, although the activity did not have a systemic impact on the behavior of the bureaucracy.

In 2014, Joko Widodo was inaugurated as president of the Republic of Indonesia, replacing Susilo Bambang Yudhoyono. During Susilo Bambang Yudhoyono's administration, bureaucracy reform was regarded as one of the development priorities. Susilo Bambang Yudhoyono's administration was able to design a Civil Servant Act which cut off a very long bureaucratic career. The law requires some technical rules that have not been drafted until now. Subsequently, several problems began to arise when Joko Widodo's administration carried out the administrative reform: 1) Regime transition leading to various increase in ministries functions, although the numbers were unchanged, 2) Weak mentality in fighting corruption that still remains among some Indonesian officials, 3) Obstacles were still found in the open recruitment which is considered as a way of selecting officials of high integrity, 4) Uncertain political situation leading to bureaucracy's inability to work properly, 5) A government structure requiring some civil servants in each level, resulting in a longwinded structure from the central government to the village, 6) There is an excessively high number of school teachers with civil servant status that Indonesia is expected to experience a "Pension Tsunami" in 2025, 7) Bureaucratic delays in implementing various technical rules, 8) inability of the Ministry of Administrative Reform in designing a systematic administration reform policies.

The administrative policy reform undertaken by Joko Widodo's administration has been halted. This suspension is more afforded to the lack of focus by the Ministry of Administrative Reform in completing various laws related to employment. One of the measures undertaken by several countries performing various administrative policy reform is civil service reform and adjustment of employee's salary (Moez Chakchouk, Danielle Kehl, Jochai Ben-Avie, Kate Coyer, 2013; Victor, 2015; Rana F. Sweis, Benjamin Lennett, Tom Glaisyer, 2013; Rastogi, Nidhi, Gloria, Joan Marie Kristine, Hendler, James, 2015). The civil service reform undertaken is also coupled with improvements in various policies.

\section{Methods and Problem Statement}

This study uses descriptive analysis based on various formal government sources. The method used in this study is triangulation of various literature review, government document data and a wide range of government conducted studies. There are four things encountered in the continuation of administrative reform under Joko Widodo's administration: 1) Politics in central and regional governments influence civil servants, and long-winded level of government, even the spirit of efficiency in government is not evident with the introduction of Law No. 23 of 2014 and Government Regulation No. 18 of 2016 on Regional Government, and Management of 
Civil Servants Human Resources in occupying certain positions; 2) Administration mentality in the society is very low with many occurrences of administrative mall; 3) System to streamline the bureaucracy through information system technology developed by a number of state administrators.

In the Indonesian Civil Service Act, there is a clause that requires civil servants to follow certain political views, but does not render them to be apolitical civil servants (without political views). Some of the higher ranking officials try to avoid this behavior yet political influence at the central and regional levels are still too strong. In some of the central government ministries, several changes in positions are not based on competence but on other grounds, for example, of the closeness of certain officials with members of a particular party. In the current political situation in Indonesia, there are two major coalitions, the Outstanding Indonesia Coalition (Koalisi Indonesia Hebat, $\mathrm{KIH}$ ) and the Red and White Coalition (Koalisi Merah Putih, KMP). In aggregate, the political interest in the Indonesian political landscape has never been this sharp, where two sides are in direct opposition to each other. Even in the last general election Jokowi's triumph was very close, leaving a number of political conflict issues that impact on the performance of the legislature and the government.

This is not an ideological conflict, but more regarding pragmatic interests. Bureaucracy as the policy implementer will follow the direction of the pragmatic ideology. The development of bureaucracy that is clean of politics is basically impossible because the bureaucracy itself was born as an executor of a wide range of political policies. But if the bureaucracy has been distorted by temporary political interest, then it becomes ineffective and inefficient for the society, as the highest stakeholder.

This political battle creates many policies that sometimes overlap with each other. An example is the policy concerning school teachers, the highest number of civil servants in Indonesia, wherein almost more than 40 percent of civil servants are school teachers. There should be a separate mechanism in determining a teacher as a civil servant, such as separating the personnel system of teachers and health workers. The principle is that if a job is monopolized by a particular group, then there will not be any competition. It is competition that creates innovation and creativity among Indonesian civil servants in the future.

Ever since the Indonesian system of government changed from centralization to decentralization, the government have 4 regional administrations, they are the central government, provincial government, city/ regency (municipal/regional government), and village administration. The more legislative products are produced by those government branches, the more difficult it is to synchronize those policies. The structure of government has been a complex subject, as illustrated by some scholars who assert that a complex structure influences the decision-making both in organizations and finance (Banerjee, 1971; Benton, 2002; Deller, 1998; Lewis, 2000; Macdonald, 2008).

Policies made by the central government as the ruling government often cannot be implemented by the local government due to differences in political views with the municipal/ regional governments. Sometimes the central government's policy is put on hold by the local government. The last surprising policy by Joko Widodo's administration is the policy concerning the village administration, which required that some of the officials in the village to be civil servants. This relatively high span of control resulted in longer decision making. On the other hand, Joko Widodo's administration guarantees to make improvements in public services. Indeed, bringing the government to the lowest level of public service should make things easier, but on the other side of the coin, the delivery of policies increasingly becomes 
more difficult, requiring months for delivering a policy to the village. Joko Widodo's regime promised to provide a budget of US $\$ 100,000$ for each village, which is intended to help the village administration in building the village and the village administration system.

The village administration as an entity of the Indonesian state system was formalized when Act No. 5 of 2014 was passed. Currently there are four levels of government in Indonesia ranging from the central to the village: the central government, provincial governments, city and regency, and village administration. The longer the chain the more complicated the decision making and service to the community. Assistance for villages in the form of huge budget requires close supervision amidst the human resources capacity in villages that is mostly less than sufficient. Villages in Indonesia is an identity which has geographic, governmental, socio-cultural bearings different to that of the city/regency.

The long-winded structure of the Indonesian government and spacious geographic location, makes the span of control by the central government to the public more difficult. This causes the decision making process to become very complex. The complexity of decision making is also exacerbated by very liberal politics. Even in preparing employee performance throughout Indonesia, there is a noticeable difference because of the extent of the capacity of employees. Upon observation of civil service jobs in Indonesia nowadays you will find that there are more and more employees with non-formal jobs than the ones with formal strategic work. This staffing capacity causes difficulty for civil servants in Indonesia to improve. Employee reduction program should be carried out as well as staff capacity improvement programs including all levels of government in the villages which have the lowest capacity of human resources in the area.

\section{Theory, Novelty and Theoretical Framework}

Identification of the sustainability of the administrative reform during Joko Widodo's administration is heavily influenced by previous factors, especially seen from the main budget priorities. Under the administration prior to Joko Widodo, the bureaucratic reform program was very huge, even local governments throughout Indonesia regarded this program as a top priority. However, if we look at the current era of Joko Widodo's administration, the budget for this program has been reduced and the government put more emphasis on the reform of infrastructure. A huge budget but not a reflection of the activity of the administrative reform is not carried out.

Novelty in this paper consists of: a. continuity of administrative reform in Indonesia at the time of the regime of President Susilo Bambang Yudhoyono became a national priority, by making bureaucratic reform as a measure of the sustainability of good governance; $b$. The regime of President Joko Widodo put administrative reform as a priority by firstly improving the functions and duties of some state institutions, organizational culture, and improvement of the civil service system. In the initial period of Susilo Bambang Yudhoyono's administration, Indonesia was in search of a proper form of Administrative Reform. Under Joko Widodo's administration, the proper form is precisely being applied in various ways. Era of discourses, discussions, academic studies, all have been performed. What is left is choosing from a wide range of options. One of the activities conducted was a study on pension. The Indonesian government (the Ministry of Administrative Reform) has started designing a program for the recruitment of civil servants since early 2005, when there were massive pension projections to occur between 2010-2019 wherein about one million employees will naturally retire. 
Various theories in some countries concerning administrative reform movement are as follows:

1. France with their measure on the impact of administrative reform on the division of the military territory (Francesca, 2016);

2. China with their focus of administrative reform on the economic process between rationalization and marketization. The administrative reform conducted in China is a lesson from the west, especially on the relations between central and local government (Chan and Xiao, 2008; Christensen, Lisheng, Painter, 2008; 2010; Foster, 2006);

3. South Korea with legal and institutional reforms supporting its administrative reform programs (Kim et. al 2015);

4. Germany by improving the pattern of relationship of the parties supporting the government and the government bureaucracy (Götz et. al, 2015);

5. Italy running the administrative reform movement by changing the accounting system of the central government with a more modern system following the development of the European Union (EU) (Liguori et. al, 2016);

6. Portugal and the Congo with existing obstacles during their administrative reform movements, one of the obstacles found in the two countries that is similar to Indonesia is the highly pluralistic cultural background of the people (Rocha et.al, 2007; Trefon, 2010);

7. Belgium alsohas a close similarity to Indonesia, particularly during the administrative reform movement in Joko Widodo's early administration, wherein a commission responsible for administrative reform was established. Indonesia established the State Civil Reform Commission in response to providing a sense of justice in the civil service, especially on positions that exerts (Thijs and Steven, 2005).
Theory and novelty in this paper will use the notion of administrative reform in Indonesia during Joko Widodo's administration that is specifically described in the administrative reform movement in the United States by Pollitt and Bouckaert (2000) called the "microlevel and macro-level" of administrative reform movements. According to Pollit and Bouckaert (2000), the micro-level is a specific tool for reform, while the macro-level is at the governance-system level. Such administrative reform movement by Pollitt and Bouckaert is further described in Durant's book (2009) wherein he divides the stages of development of the administrative reform movement into three forms: (a) history (sequencing of events, path dependency, feedback, lock-in, amplification, and reflexivity); (b) context (conjunctions of events, layering and intercurrence of institutions, friction and abrasions within and across them, institutional coupling, and venue shifting to create parallel structures); and (c) contingencies (historical-structural mismatches and interpretive effects of reforms on citizens).

\section{Discussion}

Joko Widodo's administration manage the government based on: a) firstly repairing patterns of organization; $b$ ) developing a spirit of improvement culture with the "Mental Revolution Movement"; c) open recruitment for top-level officials; d) delivery system of public services.

\section{Macro-Level; Regime Transition (Adding the Functions and Duties of Ministries without Change in Quantity)}

During Susilo Bambang Yudhoyono's era, Indonesia had 165 institutions (State Agencies, Ministries, Non-Ministries, and Ministerial Level State Agencies). In the current administration, there are 150 institutions (Institutional Performance Study Center of the Deputy for Institutional and Apparatus 
Resources, 2014). There was a reduction in the number of institutions when the transition took place from Susilo Bambang Yudhoyono to Joko Widodo. Joko Widodo also plans to design four new institutions ahead.

Several countries reforming the bureaucracy/administration also undertake similar action (Groves, 1967; Kim, 2000; Haque, 2004). South Korea, for example, streamlined various organizations during Kim Dae Jung's administration by reducing various institutions that do not support the nation's development goal. Institution reduction is common during regime transition depending on the new regime's needs to deliver its objectives. Joko Widodo's administration, for instance, promised to build "marine highways" that have never existed before. Such promise indirectly leads to the addition of the number of ministry in Joko Widodo's administration. But there are also two or three ministries that were combined into one ministry, such as the Ministry of Research and Technology in the previous administration, and the Directorate General of Higher Education which was formerly in the Ministry of National Education, both were subsequently merged under one organization, namely the Ministry of Research, Technology and Higher Education. Two functions were decidedly combined into one under a ministry.

There are 34 ministries under Joko Widodo's administration, similar to the previous era of Susilo Bambang Yudhoyono. However, in terms of workload, these ministries have additional duties. The Ministry of Administrative Reform has not had the initiative to curb this because as of current they remain focused in finding the right officials to fill those positions, widely known as open recruitment. Undoubtedly, the prerequisite of an efficient organization is a lean organization. If an agency has too many civil servants, it will bear an excessive burden for paying a large amount of money for salary alone. Political consideration is also taken into account in determining a government agency (Tucker, 1961). This can be seen in the transition from Susilo Bambang Yudhoyono to Joko Widodo, with some considerations to establish new institutions, such as Office of the President, which is an unnecessary institution in terms of bureaucratic function as there are similar institutions that already exist, however, since it is Joko Widodo's "think tank" institution, it then becomes the Office of the President.

The development of agencies in the Joko Widodo era put more emphasis on priority programs of the central government. Priority programs established by the Indonesian government led to the addition of a few institutions that can support national development, such as the activation of the Indonesian Agency for Creative Economy, the strengthening of the Maritime Security Agency of the Republic of Indonesia and the separation of various tasks and functions.

\section{Macro-Level; Eradicating Corruption and Mental Revolution}

One of the biggest problems in Indonesia nowadays is corruption in politics and bureaucracy. According to data from Transparency International, Indonesia occupies the 74th position while US and South Korea are in 17th and 43rd respectively (Transparency International, 2014). During his presidential campaign, Joko Widodo called for a revolutionary concept dubbed mental revolution, which among other translates as a revolution to be rid of corruption. The administrative reform currently undertaken is aimed at the behavior of individuals. In Indonesia, corruption tends to be a matter of tradition which had been initiated since the time of its independence (Smith, 1971). Data collected from the Corruption Perception Index 2015 indicate that Indonesia is far behind Singapore, Malaysia, and Thailand.

There were only a few changes that occurred in Indonesia regarding corruption 
Table 1.

Level and Score Perception Corruption Index 2015

\begin{tabular}{cccc}
\hline Regional Level & Global Level & Country & Score \\
\hline 2 & 8 & Singapore & 85 \\
9 & 54 & Malaysia & 50 \\
11 & 76 & Thailand & 38 \\
15 & 88 & Indonesia & 36 \\
16 & 95 & Philippines & 35 \\
17 & 112 & Vietnam & 31 \\
24 & 147 & Myanmar & 22 \\
\hline
\end{tabular}

Source: Corruption Perception Index (Transparency International Indonesia), 2015.

since its independence up to now. Corruption in Indonesia cannot be solved simply by criminalizing the perpetrators, theestablishment of a system that covers all aspects is also a necessity. The Indonesian Anti-Corruption Agency (KPK) is the organization enforcing the eradication of corruption in Indonesia, but it is not enough in strengthening the mentality of bureaucrats and politicians to escape the corruption trap. KPK is engaged in the field of law, but the improvement of the system of bureaucratic and political reforms must be carried out by the organization itself. Several studies of corruption in the United States show that it is difficult to correlate corruption and administrative reform, but to prevent bribery, embezzlement, nepotism, favoritism, conflicts of interest and even the appearance of these types of dishonesty, administrative reform is one way to do so (Jacobs, 1994).

Civil service reform is often used as a method to improve the working patterns of civil service as conducted by some of the findings of reforms in a number of countries, wherein the manner and treatment are different (Brewer, 2011; Iqbal., Et al, 2006; Reid \& Kurth, 1988; Tsao and Worthley, 2009; Burns and Xiaoqi, 2010; Ramamoorthy, 1998; Verheijen, 2007; Warwick, 1987; Witesman and Wise, 2009). Joko Widodo's administration provides a new hope to the change of mentality in his political campaign. One of the first actions taken by the government was prohibiting government organizations to hold any meetings in hotels, which was considered to be uneconomical and paving a way for corruption. However, this policy was later revised by Joko Widodo's administration after several budget considerations. There are also policies that raise some controversy, for example concerning whether official vehicles are allowed to be utilized for personal use. The use of official vehicles for personal interest is considered as corruption. Several ministries and local governments were opposed to this policy and they assumed that the Administrative Reform Ministry does not have a strong base argument to allow the use of official vehicles for personal purposes. Of the various existing polemics, Joko Widodo's administration is considered to be unresponsive to the issue of corruption at the street level bureaucrats.

\section{Micro-Level; Open Recruitment for Higher Level Officials, Between Integrity and Procedure}

Open recruitment in Indonesia was initiated by the Ministry of Finance in 2007 and this form of appointment gained popularity when Joko Widodo became the Governor of the Special Capital Region of Jakarta. This method of recruitment is then resumed when Joko Widodo became the President. Employment law in Indonesia began to change when the civil service act became effective in 2014. In the 19th century, the vision of civil service reform was to avoid patronage, cronyism, and graft (Smith, 1971). One way to avoid patronage in the appointment of high-ranking officials in state bureaucracy is by having an open recruitment system. The previous Civil Service Act in Indonesia did not allow for such an open recruitment. The designation method used at the time lead to corruption, collusion, and nepotism. Positional adjustment based on this new method is very complicated because the appointed official must demonstrate professionalism in his or her previous work, be committed to prevent 
corruption and be competitive. The purpose of these requirements is to have a variety of integrity in the performance or behavior. A wide variety of tests are used simultaneously within 2 to 3 months. Such complicated procedure hampers the budget disbursement for the development of Indonesia that is currently in the midst of an unfavorable economy, wherein government budget has not been able to boost the Indonesian economy. Up to now, there has not been any study that integrates open recruitment with the performance of officials, even so this recruitment is considered to be the most reformist recruitment in comparison to the closed recruitment commonly held in the past. Several recruitment systems for government officials are often discussed in a number of countries (Chan, 2003; Fukai and Fukui, 1992; Gusfield, 1958; Koh, 1985; Kundra, 1957; Nachmias, 1957).

In reforming Indonesian civil servants, the Ministry of Administrative Reform designed a variety of variables, namely in determining employee needs, procurement, development, performance assessment, discipline, rewards, termination, salaries and allowances, pension and old age security and protection. Table 2 illustrates the change in management for full time civil servants (PNS) and contractual government employees (PPPK). For PNS and PPPK, determining the needs is based on job load and work load by using applications developed by the ministry, namely e-formation. The system used for the procurement is an online Computer Assisted Test (CAT). The development of PNS and PPPK also use qualifications, performance and competence, whereas PNS may follow the open recruitment and training to fulfill the need for officials.

In assessing PNS performance, SKP (Employee Performance Targets) and $360^{\circ}$ Assessment, which is an assessment method involving all stakeholders and including the user of the employee. On the other hand, the performance assessment for PPPK is conducted through contract-based performance. Problems

Picture 1.

Indonesia Civil Servant Management Reform

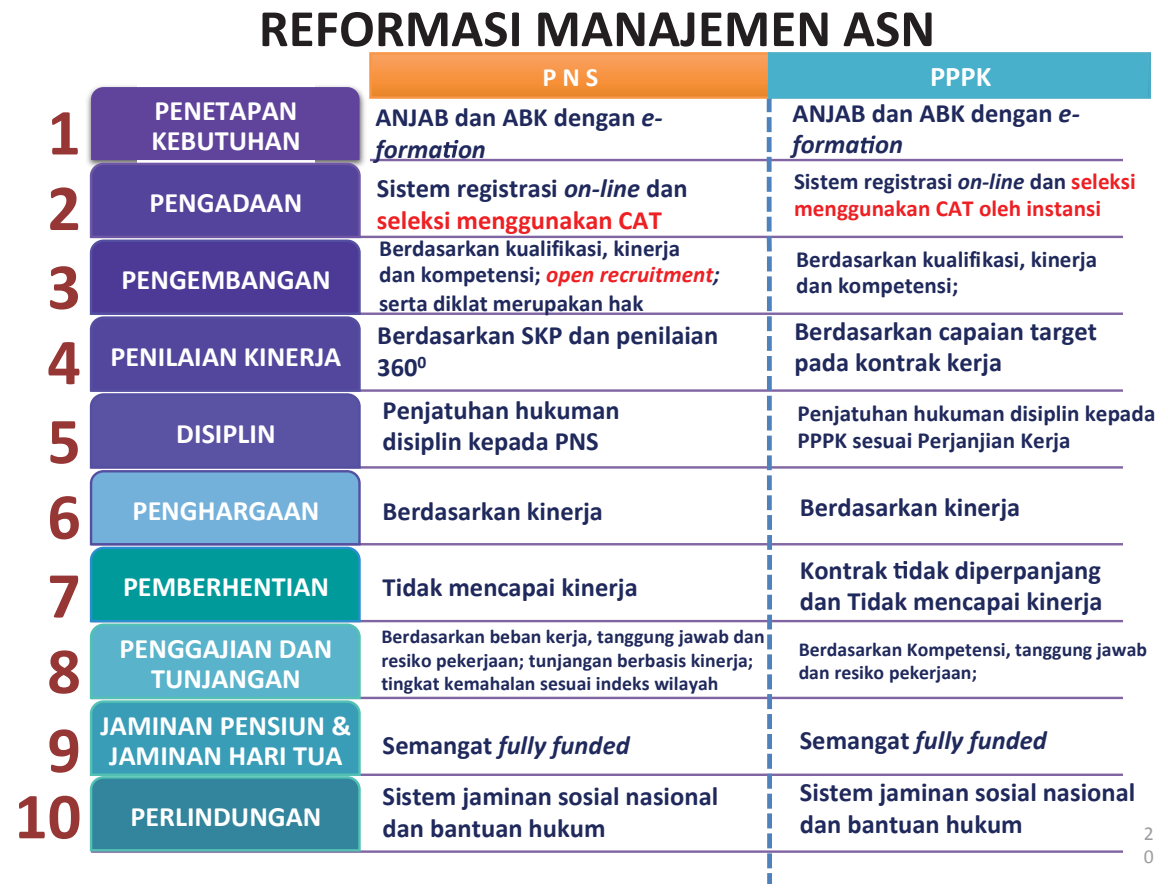

Source: General Lecture at Padjadjaran University Bandung, $4^{\text {th }}$ of April, 2016 
of discipline, rewards, and termination of PNS and PPPK will follow a system of discipline and performance awards and they can even be terminated if they do not comply to the work output. The salary and benefit system is also changing, especially the system of benefit following the pattern of the existing work load. The pension and old age security system use a fully funded approach, which is financed by the government. PNS and PPPK protection is provided by the Social Security Agency (BPJS).

In developing employee performance policy, it is necessary to develop an application to help assessors assess the employees in order to generate information for the employee coaching process; to generate a system of employee performance evaluation information by sector/division in order for leaders to know the performance in every sector/division, because this information will be analyzed for the coaching process; to generate job promotion information system to help the leaders know whether an employee is eligible to be promoted or not; to generate historical employment performance evaluation information system that will subsequently produce annual report.

There are several ways to measure employee performance in Indonesia, but in this paper I will only discuss about individual performance. There are several forms of performance that can be measured: organization performance, organizational unit performance, and budget performance. These performances are interrelated and mutually exclusive. They are intertwined in terms of individual performance being influenced by budget availability and that the organization and its unit affects competition among individuals. They are also mutually exclusive from each other in terms of individual performance being used to measure competencies of individuals who are obviously going to be different from each other.

To support a performance-based allowance in accordance with Law No. 5 of
2014 concerning the state civil apparatus that strengthens the mandate contained in the Ministerial Regulation No. 63 Year 2011 on Guidelines for the Management of Civil Servant Performance Benefit System. According to the law, civil servants are entitled to salaries, facilities, performance benefits, and expensiveness allowances (based on the varied cost of living in each region). The Act explains that any civil servant with outstanding performance deserve a raise according to their achievements. Measurement of employee performance achievements have been stipulated in the Government Regulation No. 46 Year 2011 on Job Performance Assessment of Civil Servants. According to the said government regulation, performance appraisal of civil servants is conducted to ensure the objectivity of civil servant coaching in considering promotions, placement in the office, transfer, education and training, learning assignment, periodical salary increases, and others carried out based on the system performance and career system that focus on performance system. Performance appraisal of civil servants carried out by assessors of the Employee Working Target (SKP) and working behavior of civil servants. By conducting work performance assessment, provision of benefits will be fairly provided, considering that a well-performed civil servant will receive better benefits than other civil servants.

The problem currently faced by the Indonesian bureaucracy is a classic one confronted by a number of developing countries. It is the issue of the ratio of civil servants with good performances to those lacking proficiency. The management of civil servants undertaken by the Indonesian government constantly has its ups and downs, starting with the strengthening of civil servant oligarchy. Indications of the presence of this oligarchy is the emergence of civil servants as a strength in building a political system. Principles of mutual interest between the bureaucracy 
and politicians become important in current corruption issues. To sever this mutualism, politics is required to reform itself, restore public confidence and compel the bureaucracy to be more professional.

Building a professional bureaucracy in Indonesia is a challenge due to the diverse characteristics of bureaucracy in Indonesia. Bureaucracy has a specific duty and particular task, not to mention a wide geographical range, taking care of people in remote areas to the globalization of the world. A dynamic performance understanding is needed in dealing with this. The dynamic performance assessment is commenced by measuring the current state of performance of the bureaucracy. Some mistakes in the performance of bureaucratic procedures currently exist on the placement of bureaucracy in which it is merely regarded as a means rather than a national asset. If the tool is not maintained then total breakdown is inevitable. To avoid total damage, the central government builds a rule-based regulation. This rule is binding, but too many binding rules should also be avoided.

One of the factors that contribute to the failure of Joko Widodo's administration to increase Indonesia's economic growth at the onset of his presidency is the open recruitment procedure which is time consuming (it takes 3 to 4 months) which consequently affects the budgetary-related decision making process carried out by the appointed official. Cabinet reshuffle has been a very hot issue because a number of ministers are not able to improve the capacity of some officials in their ministries. The role of the Ministry of Administrative Reform to speed up the procedure through these unresponsive regulations impedes the acceleration of national development in comparison to that of the previous leadership. Besides integrity factors (commitment and consistency), the success of open recruitment also depends on a cultural transformation in the bureaucracy. One that is offered for such transformation is the idea of mental revolution introduced by Joko Widodo. In the Indonesian culture, which is highly influenced by Islamic culture, the notion of "applying" for a position is regarded as the greatest taboo for an employee to do, while one form of seeking a good and prospective public manager is to openly provide the widest opportunities for employees to participate in applying as an official. A hadith says: "Do not give the post to those who request it". Open recruitment program encourages civil servants to "ask" for positions according to their wishes and choices. In order to minimize this cultural bias, it is proposed that PNS applying for the open recruitment program are to be provided with administrative legality in the form of a letter of assignment to apply for it.

Leadership involves the process of social influences and effects deliberately used by a person on another person to organize the activities and relationships within the organization. The most important factor in leadership is to interpret events, map the course of the organization, and build cooperation among members of the organization to achieve its intended goals. No matter how small the organization is, the role of a leader is very dominant in creating, developing, maintaining and enhancing cooperation both vertically, horizontally and diagonally. It affects all subordinates or followers in order to provide service to achieve organizational goals.

Globalization and reform era, change in the order of society, nation and state to quickly follow the development of the international world. Leaders and leadership of governmental organizations in general and urban village government in particular have become a major public concern both qualitatively and quantitatively. Along with the demands of society and the needs of the time, a quality leader is in demand so that public services can meet the needs of society in a fast, effective and accountable manner. However, until recently 
most people stated that the management of urban village remains unable to optimally serve the needs of the society.

Unification of perception and action on the implementation of basic tasks and functions of the organization, a leader needs to pay attention to what is called the culture of the organization. Organizational culture is a matter that can be engineered towards a better cultural change. Leaders are required to provide role models and public employees in the organizational environment of values is enforced. The role of leaders in creating organizational culture must be planned and directed to all members of the organization.

Cultural values in urban village offices (kelurahan) still need to be improved, developed or even eliminated wherein the process undeniably requires a relatively extended amount of time. The behavior of the members of the organization is a reflection of cultural values embraced by the organization. Building basic assumptions, beliefs and norms such as proper etiquettes, how to speak, how to provide public services, build unity, spatial planning and other work are the demands and challenges for a leader to accomplish and overcome. On the other hand, most public opinions state that there are many employees of urban village administrations who do not give the impression as public servants but as people asking to be served. This is indicated by the fact that when people need services, they must occasionally go through difficult procedures and sometimes violate the norms and regulations that have been set.

In line with the increasing demands for rights that must be accepted by the society, the performance of urban village administration employees is gaining more and more attention from formal and higher institutions, social institutions and society in general. This can be regarded as a natural consequence as the urban village administration is the leading government organization dealing directly with the public. Any activity that occurs in the urban village will be seen by the public as the responsibility of the urban village administration. The performance of urban village administration employees is easily noticed and assessed by the public. People consider the performance of urban village administration employees have not been able to optimally respond to the needs of the urban village community. All employees of urban village administrations require extra attention from various parties as a consideration for policy makers, in order to realize the people's expectation.

Regarding all aspects of public services, the urban village employees have not been able to optimally respond to people's needs due to various factors, such as, shortage of human

Picture 2.

Hierarchical Rank/Level of Civil Servant

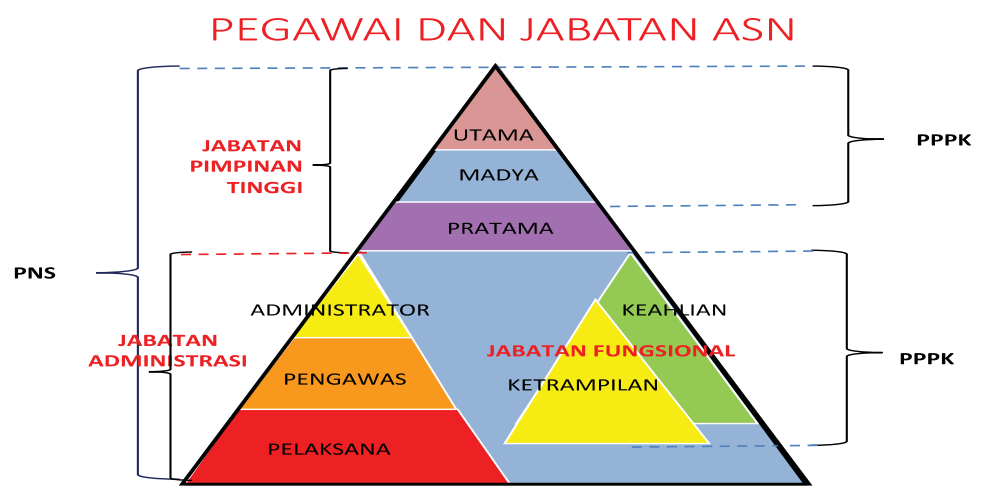

Source: General Lecture at Padjadjaran University Bandung, $4^{\text {th }}$ of April, 2016 
resources in terms of both quantity and quality, inadequate office facilities and infrastructure, limitations of budget support and authority and others.

The four levels of Indonesian government structure further complicate the recruitment of the best officials in a government organization. Open recruitment will be applied to all lines in the appointment of bureaucratic officials. The method is also time and cost consuming, for example, the use of this method generally consumes 2-3 months time, whereas the needs of organizations require a faster solution.

\section{Micro-Level; Electronic Delivery System in Public Service, Informative Instead of Transactional}

In terms of usability features, a large majority of countries provide users with basic search tools to locate content, and most now do so in more than one language. However, only about half of the United Nations member states maintain an advanced search engine, only 40 percent enable user opinion features, such as tag clouds and 'hot topics' lists and less than one third show the availability of a secure connection. There also appears to be substantial underutilization of the potential of text-based Short Message Service (SMS) despite the dramatic global growth of mobile devices usage, including in low income countries. The most frequently found transactional services include setting up of personal online accounts, income tax filing and business registration, but overall there is great diversity in types (UN, 2014).

Although sustainable development challenges have significantly changed over the past decades and are becoming increasingly interdependent, government institutions and their functions are still largely shaped by early 20th century models of public administration in which ministries and their leaders work in "silos" and issues are tackled through a sectorial rather than a collaborative perspective.
At the same time, citizens and businesses are demanding more open, transparent, accountable and effective governance, while new technologies, especially ICT, are enabling effective knowledge management, sharing and collaboration between all sectors and at all levels of government whether cross-border, national or local (UN, 2014).

Electronification of various public service system is used to facilitate various services to the society. The development of this system is not something new in Indonesia. Electronification has been developed since 2000, but its development is still partially undertaken between one institution and the other, so there are "islands of electronic" in various institutions that actually extend the information network. Ease of use in the electronic system is still very limited both in its transactional or analytical form. This causes the "islands of electronics" to expand and hamper the delivery system of public services in the central and local government, if they are not immediately mapped.

Interconnection between one "electronic island" with another requires some coordination and collaboration in building networks that are connected to each other. For example, the population census conducted by the Indonesian National Police (INAFIS) and electronic identity card (e-KTP) are two electronification programs that the police and the Interior Ministry need, but both contain the same information. Coordination and collaboration among ministries and agencies create too many websites or applications that stand alone causing the electronification program in Indonesia to remain incomprehensive.

These websites or applications are still digging up information, and they have yet to reach the stage of analysis or transactional process. A master plan is needed to bring together a variety of applications in both the central and local government. Such master plan is useful to be developed into a policy of 
Picture 3.

Homepage View of eCitizen of Singapore Government

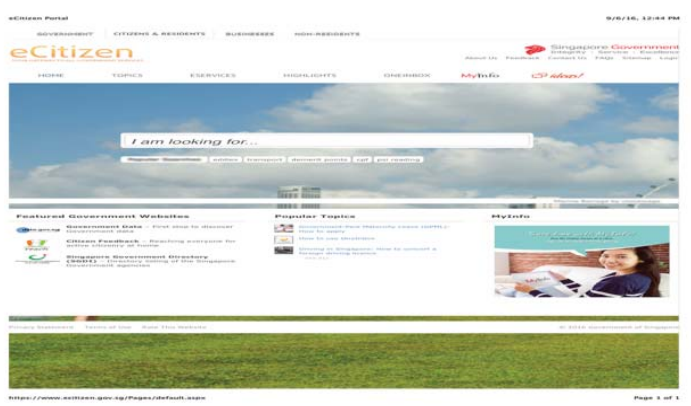

Source: https://www.ecitizen.gov.sg/Pages/default. aspx, accessed on 6 September 2016, 12.52 .

one e-government for all. Indonesia should emulate something that has been done by the Singapore government on their site http:// ecitizen.gov.sg, where all public services and related purposes related to the Singapore government is connected in one application to be transacted to the various units or institutions concerned.

\section{Conclusion}

The current Joko Widodo's administration is stagnant in conducting its administrative reform. Various kinds of existing policies remain in a bottleneck, especially persistence of :

1. Bureaucratic and society barriers culture.

2. Politicians in Indonesia still utilize the bureaucracy as a political servant rather than as a public servant.

3. Siezed and hierarchical of government.

4. Overlapping functions in government institutions.

5. Decentralization remains problematic regarding the division of tasks between the central and local governments and villages.

6. Electronification remains a bottleneck at the informational stage and has yet to reach the transactional stage.
Challenges for bureaucratic reform in Indonesia must be transformed into a revolutionary because this reform is a very long process. There needs to be some improvement of community mentality, one of its forms is a mental revolution that should be made in a value or a new culture for the bureaucracy in Indonesia. Administration reform under Joko Widodo's administration is more about improving the administrative process in technical matters rather than a comprehensive improvement in public policy. Trimming a wide range of policies that impede administration process can be assisted by the process of e-government which is currently being intensively carried out by the central government.

\section{References}

Artioli, Francesca. (2016). When Administrative Reforms Produce Territorial Differentiation. How Market-Oriented Policies Transform Military Brownfield Reconversion in France (1989-2012). Environment and Planning C: Government and Policy.

Banerjee, Sumanta. (1971). Cracks in the Government Structure. Economic and Political Weekly, p. 14-16.

Bellé, Nicola, Ongaro, Edoardo. (2014). NPM, Administrative Reforms and Public Service Motivation: Improving the Dialogue between Research Agendas. International Review of Administrative Sciences. Vol. 80 (No.2), p. 382-400.

Benton, J. Edwin. (2002). County Service Delivery: Does Government Structure Matter? Public Administration Review. Vol. 62, p. 471-479.

Brewer, Brian. (2011). Civil Service Reform: In Lam, Newman M. K., Scott, Ian, ed. Building Basic Administrative Capacity. Gaming, Governance and Public Policy in Macao. Hong Kong University Press. p. 89-106.

Brewer, Gene A., Kellough, J. Edward. (2016). Administrative Values and Public Personnel 
Management: Reflections on Civil Service Reform. Public Personnel Management, 45 (2), p. 171-189.

Burns, John P. (1987). Civil Service Reform in Contemporary China. The Australian Journal of Chinese Affairs (18), p. 47-83.

Burns, John P., Xiaoqi, Wang. (2010). Civil Service Reform in China: Impacts on Civil Servants' Behaviour. The China Quarterly (201), p. 58-78.

Chan, Che-po, Xiao, Ren. (2008). The Shanghai Administrative Reform in the Last Decade: More Rationalisation and Marketisation? China Report, 44 (3), p. 233-249.

Chan, Hon S. (2003). The Civil Service under One Country, Two Systems: The Cases of Hong Kong and the People's Republic of China. Public Administration Review, 63, p. 405-417.

Christensen, Tom, Lisheng, Dong, Painter, Martin. (2008). Administrative Reform in China's Central Government - How Much 'Learning from the West'? International Review of Administrative Sciences, 74 (3), p. 351 -371.

Deller, Steven C. (1998). Local Government Structure, Devolution, and Privatization. Review of Agricultural Economics, 20, p. 135154.

Durant, Robert F. (2009). Theory Building, Administrative Reform Movements, and the Perdurability of Herbert Hoover. The American Review of Public Administration, 39 (4), p. 327-351.

Ford, Henry Jones. (1900). Political Evolution and Civil Service Reform. The Annals of the American Academy of Political and Social Science, 15, p. 15.

Foster, Kenneth W. (2006). Improving Municipal Governance in China: Yantai's Pathbreaking Experiment in Administrative Reform. Modern China, 32 (2), p. 221-250.

Fukai, Shigeko N., Fukui, Haruhiro. (1992). Elite Recruitment and Political Leadership. PS: Political Science and Politics, 25, p. 25-36.

Götz, Alexander, Grotz, Florian, Weber, Till. (2015). Party Government and
Administrative Reform: Evidence Ffrom the German Länder. Administration \& Society. Groves, R. T. (1967). Administrative Reform and the Politics of Reform: The Case of Venezuela. Public Administration Review, 27 (5), 463-445.

Gusfield, Joseph R. (1958). Equalitarianism and Bureaucratic Recruitment. Administrative Science Quarterly, p. 521-541.

Haque, M. S. (2004). Governance and Bureaucracy in Singapore Contemporary Reforms and Implications. International Political Science Review , 25 (2), 227-240.

Iqbal, Muhammad, Ahmad, Eatzaz. (2006). Is Good Governance an Approach to Civil Service Reforms? [with comments]. The Pakistan Development Review, 45, p. 621-637. Jacobs, F. A. (1994). Visions of Corruption Control and the Evolution of American Public Administration. Public Administration Review , 54 (5), 465-473.

Karch, Andrew. (2007). Emerging Issues and Future Directions in State Policy Diffusion Research. State Politics \& Policy Quarterly, p. 54-80.

Kim, P. S. (2000). Administrative Reform in the Korean Central Government: A Case Study of the Dae Jung. Public Performance and Management Review, 24 (2), 145-160.

Kim, Sunhyuk, Han, Chonghee. (2015). Administrative reform in South Korea: New Public Management and the Bureaucracy. International Review of Administrative Sciences, 81 (4), p. 694-712.

Koh, B. C. (1985). The Recruitment of Higher Civil Servants in Japan: A Comparative Perspective. Asian Survey, 25, p. 292-309.

Kundra, J. C. (1957). Comparative Recruitment Methods in the Civil Service. The Indian Journal of Political Science, 18 (3/4), p. 260267.

Lewis, Paul G. (2000). The Durability of Local Government Structure: Evidence from California. State \& Local Government Review, 32, p. 34-48. 
Liguori, Mariannunziata, Steccolini, Ileana, Rota, Silvia. (2016). Studying administrative reforms through textual analysis: the case of Italian central government accounting. International Review of Administrative Sciences.

Lisheng Dong, Christensen, Tom, Painter, Martin. (2010). A Case Study of China's Administrative Reform: The Importation of the Super-Department. The American Review of Public Administration, 40 (2), p. 170-188.

MacDonald, Lynn. (2008). The Impact of Government Structure on Local Public Expenditures. Public Choice, 136 (3/4), p. 457-473.

Milkis, Sidney M., (1987). The New Deal, Administrative Reform, and the Transcendence of Partisan Politics. Administration \& Society, 18 (4), p. $433-472$.

Moez Chakchouk, Danielle Kehl, Jochai BenAvie, Kate Coyer. (2013). From Revolution to Reform: Recommendations for Spectrum Policy in Transitional Tunisia. Journal of Information Policy, p. 575-600.

Mooney, Christopher Z. (2001). Modeling Regional Effects on State Policy Diffusion. Political Research Quarterly, 54, p. 103-124.

Nachmias, David. (1991). Israel's Bureaucratic Elite: Social Structure and Patronage. Public Administration Review, 51, p. 413-420.

Pickard, Victor. (2015). Media Activism from Above and Below: Lessons from the 1940s American Reform Movement. Journal of Information Policy, p. 109-128.

Pollitt, C., and Bouckaert, G. (2000). Public management reform: A comparative analysis. Oxford, UK: Oxford University Press.

Pusat Kajian Kinerja Kelembagaan Deputi Bidang Kelembagaan dan Sumber Daya Aparatur. (2014). Kajian Desain Kelembagaan Pemerintah Pusat (Arsitektur Kelembagaan tahun 2014-2019). Jakarta: Lembaga Administrasi Negara.

Ramamoorthy, K. (1998). Reforming Civil Service. Economic and Political Weekly, 33 (12), p. 676-676.
Rana F. Sweis, Benjamin Lennett, Tom Glaisyer. (2013). Spectrum Policy Reforms:Supporting Democracy and Economic Development in Jordan. Journal of Information Policy, p. 552574.

Rastogi, Nidhi, Gloria, Marie Joan Kristine, Hendler, James. (2015). Security and Privacy of Performing Data Analytics in the Cloud: A Three-way Handshake of Technology, Policy, and Management. Journal of Information Policy, p. 129-154.

Reid, Joseph D., Kurth, Michael M. (1988). Public Employees in Political Firms: Part A. The Patronage Era. Public Choice, 59, p. 253-262.

Reid, Joseph D., Kurth, Michael M. (1989). Public Employees in Political Firms: Part B. Civil Service and Militancy. Public Choice, 60, p. 41-54.

Republik Indonesia. Undang-Undang No. 5 Tahun 2014 tentang Aparatur Sipil Negara.

. Peraturan Menteri Nomor 63 Tahun

2011 tentang Pedoman Penataan Sistem Tunjangan Kinerja Pegawai Negeri. . Peraturan Pemerintah No 18 Tahun

2016 tentang Perangkat Daerah. . Undang-Undang No 23 Tahun 2014 tentang Desa. . Undang-Undang No 30 Tahun 2014 tentang Pemerintahan Daerah.

Rocha, J.A. Oliveira, Ferraz Esteves de Araujo, Joaquim Filipe. (2007)/12/01. Administrative reform in Portugal: problems and prospects. International Review of Administrative Sciences, 73 (4), p. 583-596.

Schafer, M. (1997). Images and Policy Preferences. Political Psychology, Vol. 18, No. 4 (December, 1997), pp. 813-829, 18 (4), p. 813-829.

Shaw, C. K. (1992). Hegel's Theory of Modern Bureaucracy. The American Political Science Review, 86 (2), p. 381-389.

Shipan, Charles R., Volden, Craig. (2008). The Mechanisms of Policy Diffusion. American Journal of Political Science, 52, p. 840-857. 
Smith, T. M. (1971). Corruption, Tradition and Change. South East Asia Publication, 11, 21-40.

Sugandi, Y. S. (2011). Administrasi Publik Konsep dan Perkembangan Ilmu di Indonesia. Yogyakarta: Graha Ilmu.

Thijs, Nick, Van de Walle, Steven,. (2005). Administrative Reform Movements and Commissions in Belgium, 1848-2004. Public Policy and Administration, 20 (4), p. 38-54.

Transparency International. (2014). Corruption Perception Index. www.transparency.org/ cpi.

Trefon, Theodore. (2010). Administrative obstacles to reform in the Democratic Republic of Congo. International Review of Administrative Sciences, 76 (4), p. 702-722.

Tucker, Robert, C. (1961). Towards a Comparative Politics of Movement-Regimes. The American Political Science Review, 55, p. 281-289.

Tsao, King Kwun, Worthley, John Abbott. (2009). Civil Service Development in China and America: A Comparative Perspective. Public Administration Review, 69, p. S88-S94.

United Nation for Public Administration Networks. (2014). United Nation
E-Government Survey 2014; E-Government for the Future We Want. New York. Division for Public Administration and Development Management (DPADM) of UNDESA.

Verheijen, Tony J. G. (2007). Independent Civil Service Systems: a Contested Value? Zeitschrift Staats- und Europawissenschaften (ZSE)/Journal for Comparative Government and European Policy (3/4), p. 540-556.

Volden, Craig, Ting, Michael M., Carpenter, Daniel P. (2008). A Formal Model of Learning and Policy Diffusion. The American Political Science Review, 102, p. 319-332.

Wangsaatmaja, Setiawan. (2016). Manajemen ASN (PNS dan PPPK) menuju worldclass Government". Kuliah Umum Universitas Padjadjaran 4 April 2016, Bandung.

Warwick, Donald P. (1987). The Effectiveness of the Indonesian Civil Service. Southeast Asian Journal of Social Science, 15, p. 40-56.

Witesman, Eva M., Wise, Charles R. (2009). The Centralization/Decentralization Paradox in Civil Service Reform: How Government Structure Affects Democratic Training of Civil Servants. Public Administration Review, 69, p. 116-127. 